\begin{tabular}{|c|c|c|}
\hline \multicolumn{3}{|c|}{ TOTOBUANG } \\
\hline Volume 6 & Nomor 2, Desember 2019 & Halaman 313-329 \\
\hline
\end{tabular}

\title{
TIPE NARATOR DALAM NOVEL TELEGRAM KARYA PUTU WIJAYA: KAJIAN NARATOLOGI (Type of Narrator in Novel Telegram By Putu Wijaya: Narratology Approach)
}

\author{
A. Yusdianti Tenriawali a ${ }^{\text {, Susiati }}{ }^{\text {b }}$, \& Andi Masniati ${ }^{\text {c }}$ \\ a,b,c Universitas Iqra Buru \\ Jl. Prof. DR. H. A.R. Bassalamah, SE.,M.Si Fax/Tlp (0913) 21909 \\ Namlea, Kab. Buru \\ Pos-el: tenriawali@gmail.com
}

(Diterima: 21 November 2018; Direvisi: 6 Desember 2018; Disetujui: 10 Desember 2018)

\begin{abstract}
This study discusses the type of narrator in novel Telegram by Putu Wijaya. This study aims to identify the types of narrators contained in the novel Telegram by Putu Wijaya based on Mieke Bal's narratology theory. This research is qualitative research using descriptive methods. The data in this study are texts that are considered to represent the narrator in the novel Telegram. The source of the data in this study was the novel Telegram by Putu Wijaya, which was published in 1977. The data collection techniques in this study were the reading and note-taking techniques. The data analysis techniques in this study consist of four stages; narrator identification, narrator text classification, analysis, and description of the types of narrators in each chapter. The results showed that the type of narrator in the novel Telegram by Putu Wijaya consisted of an internal narrator (CN), a figure of Aku and Rosa, and an external narrator (EN), something that was unknown. The use of an internal narrator $(C N)$ aims to give the impression that what is told in a story is real. The use of an external narrator (EN) aims to inform the reader that the story contained in the text that is being read is a fantasy, imagination, or imaginary story contained in the story or story that is being read.
\end{abstract}

Keywords: Narrator, Novel, Narratology

\begin{abstract}
Abstrak
Penelitian ini membahas tipe narator dalam novel Telegram karya Putu Wijaya. Penelitian ini bertujuan mengidentifikasi jenis-jenis narator yang terdapat dalam novel Telegram karya Putu Wijaya berdasarkan teori naratologi Mieke Bal. Penelitian ini merupakan penelitian kualitatif dengan menggunakan metode deskriptif. Data berupa teks yang dianggap merepresentasikan narator dalam novel Telegram. Sumber data yakni novel Telegram karya Putu Wijaya yang terbit tahun 1977. Teknik pengumpulan data yakni teknik baca dan teknik catat. Adapun teknik analisis data terdiri atas empat tahap yaitu identifikasi narator, klasifikasi teks narator, analisis, dan deskripsi jenis-jenis narator tiap bab. Hasil penelitian menunjukkan bahwa tipe narator dalam novel Telegram karya Putu Wijaya terdiri atas narator internal (CN) yaitu tokoh Aku dan Rosa, serta narator eksternal (EN) yaitu sesuatu yang tidak diketahui identitasnya. Penggunaan narator internal (CN) bertujuan untuk memberi kesan bahwa yang diceritakan dalam suatu cerita adalah nyata. Adapun penggunaan narator eksternal (EN) bertujuan menyatakan kepada pembaca bahwa cerita yang terdapat dalam teks yang sedang dibacanya adalah suatu khayalan, imajinasi, atau cerita rekaan yang terdapat dalam kisah atau cerita yang sedang dibacanya.
\end{abstract}

Kata-kata Kunci: narator, novel, naratologi

\section{PENDAHULUAN}

Secara umum objek kajian sastra meliputi teks, pengarang, dan masyarakat. Namun di antara ketiga objek kajian sastra tersebut (teks, pengarang, dan masyarakat), namun objek yang paling sering diteliti adalah teks atau dalam hal ini karya sastra. Pengelompokkan karya sastra secara umum terdiri atas puisi, prosa, dan drama, dan di antara ketiganya yang sering dijadikan objek penelitian sastra adalah novel yang termasuk dalam kelompok prosa.

Novel adalah salah satu karya sastra yang memiliki kisah atau cerita di dalamnya. Alur cerita dan penceritaan dalam novel merupakan unsur dari novel, sebab dalam 
cerita dan penceritaan tersebutlah terekam aktivitas kultural. Melalui cerita dalam novel dapat diketahui aktivitas kultural yang berlangsung. Persoalan tentang konsep cerita dan penceritaan termasuk dalam kajian naratologi.

Naratologi merupakan cabang dari strukturalisme yang mempelajari struktur naratif suatu cerita. Hal ini sesuai dengan definisi kata naratologi yang berarti ilmu tentang cerita atau teori wacana (teks) naratif. Konsep-konsep yang berkaitan dengan naratologi berbeda-beda, sesuai dengan para penggagasnya. Namun dalam penelitian ini teori naratologi yang akan digunakan adalah teori naratologi dari Mieke Bal.

Novel Telegram karya Putu Wijaya adalah salah satu karya sastra yang menarik, sebab dari sisi penceritaan, novel ini menggunakan sudut pandang pencerita utama yang didukung oleh pencerita pendamping yang membuat pembaca melihat berbagai rangkaian peristiwa yang terjadi dalam novel tersebut dari berbagai perspektif. Dari sisi alur cerita, novel Telegram ini juga menarik sebab rangkaian cerita dalam novel ini diselingi oleh fantasi tokoh utama sehingga menjadikan cerita dalam novel ini menjadi lebih kompleks. Oleh karena itu, rumusan masalah dalam penelitian ini adalah bagaimana tipe narator dalam novel Telegram karya Putu Wijaya. Fokus penelitian ini adalah mengungkap tipe atau jenis-jenis narator yang terdapat dalam novel, sehingga diharapkan penelitian ini dapat menunjukkan bentuk analisis narator pada novel Telegram yang dapat membantu pembaca dalam mengungkap makna dalam novel tersebut.

Penelitian yang menggunakan teori naratologi telah banyak dilakukan, namun penelitian yang menggunakan teori naratologi Bal, berdasarkan pengetahuan peneliti masih sangat sedikit. Hal ini terlihat dari sedikitnya tulisan yang peneliti temukan yang menyangkut teori naratologi Bal, biarpun ada tulisan ataupun artikel mengenai teori naratologi, teori naratologi Bal hanya sedikit dibahas dalam artikel tersebut. Penelitian yang menggunakan teori naratologi Bal berdasarkan sepengetahuan peneliti pernah ditulis oleh U'um Qomariyah dengan tesisnya yang berjudul 'Citra dan Pencitraan Anak dalam Novel Negeri Awan Merah Karya Fahri Asiza: Telaah Fokalisasi Mieke Bal', yang dalam tesisnya, Qomariyah menganalisis novel Negeri Awan Merah tersebut dari perspektif fokalisasi berdasarkan teori naratologi Mieke Bal untuk mencari fokalisasi yang mengimplikasikan adanya relasi tarik menarik antara orang tua dan anak. Serta, Aslan Abidin dengan tesisnya yang berjudul 'Tubuh Terjajah dalam Novel Perburuan Karya Pramoedya Ananta Toer Sebuah Perspektif Pascakolonial'. Dalam penelitian ini, teori naratologi Bal yang khususnya fokalisasi digunakan oleh peneliti sebagai metode dalam menganalisis teks novel Perburuan. Analisis fokalisasi digunakan untuk mengetahui bagaimana tubuh dipandang, dimaknai, dan diperlakukan dalam novel tersebut.

Mengingat penelitian yang menggunakan teori naratologi Bal masih sangat sedikit, hal inilah yang mendasari peneliti tertarik untuk menganalisis novel Telegram karya Putu Wijaya berdasarkan Teori Naratologi Mieke Bal. Dalam penelitian ini, peneliti akan memfokuskan penelitian terhadap analisis narator dalam novel Telegram berdasarkan teori naratologi Bal.

\section{LANDASAN TEORI Naratologi}

Naratologi adalah salah satu cabang dari strukturalisme. Tentang strukturalisme dalam penelitian sastra, Pradopo (dalam Rahmah, 2007:22) mengemukakan bahwa satu konsep dasar yang menjadi ciri khas teori strukturalisme adalah adanya anggapan bahwa di dalam dirinya sendiri karya sastra merupakan suatu struktur yang otonom yang dapat dipahami sebagai kesatuan yang bulat dengan 
unsur-unsur pembangunnya yang saling berjalinan. Oleh karena itu, untuk memahami maknanya, karya sastra harus dikaji berdasarkan strukturnya sendiri, lepas dari latar belakang sejarah, lepas dari diri dan niat penulis, dan lepas pula dari efeknya pada pembaca. Teeuw (2003:112) berpendapat bahwa analisis struktural bertujuan untuk membongkar dan memaparkan secermat, seteliti, sedetail, dan sedalam mungkin keterkaitan dan keterjalinan semua anasir dan aspek karya sastra yang bersama-sama menghasilkan makna menyeluruh.

Naratologi berasal dari kata narratio dan logos (bahasa Latin). Narratio berarti cerita, perkataan, kisah, hikayat; logos berarti ilmu. Naratologi juga disebut teori wacana (teks) naratif. Baik naratologi maupun teori wacana (teks) naratif diartikan sebagai seperangkat konsep mengenai cerita dan penceritaan (Hudayat, 2007:78). Naratologi awalnya digunakan dalam meneliti cerita rakyat, kemudian berkembang pada penelitian mitos dan dongeng, dan selanjutnya berkembang pada penelitian novel.

\section{Narator}

Narator adalah pencerita atau dengan kata lain siapa yang bercerita dalam suatu teks. Sesungguhnya siapa yang dimaksud dengan pemberi narasi? Sejauh ini, ada tiga gagasan yang berusaha untuk menjawab pertanyaan ini. Pandangan pertama mengatakan bahwa narasi berasal dari seorang pribadi (pribadi dalam pemahaman psikologis). Pribadi ini memiliki sebutan, yakni pengarang, seseorang yang padanya terjadi pengadukan atau percampuran terusmenerus 'personalitas' dan 'seni' individual yang teridentifikasi dengan jelas, seseorang yang pada suatu waktu mengambil penanya untuk menulis cerita: narasi (khususnya novel) lalu menjadi semata-mata ekspresi dari seorang $a k u$ yang berada di luar narasi atau tidak disebutkan dalam narasi. Pandangan kedua mengakui narator sebagai sang maha tahu, yang impersonal (tak berwujud pribadi), kesadaran yang bercerita dari sudut pandang superior, seseorang yang mirip Allah: narator pada saat bersamaan ada di dalam karakter-karakter yang ia ciptakan (karena ia mengetahui segala sesuatu yang mereka alami) sekaligus berjarak dengan karakter-karakter tersebut (karena ia tidak pernah bisa diidentikkan dengan karakter tertentu). Pandangan ketiga dan paling baru (Henry James, Sartre) menyatakan bahwa narator harus membatasi narasinya pada apa yang bisa diamati dan diketahui oleh karakter-karakter yang ia cipta, narasi diusahakan agar seolah-olah setiap karakterlah yang menjadi pengirim narasi. Namun, menurut Barthes, ketiga pandangan di atas susah diterima karena meyakini narator dan karakter sebagai orang-orang riil atau sungguh 'hidup' (kekuatan mitos kesusastraan ini tak ada habisnya dan sudah diketahui luas), seakanakan kesejatian narasi pada dasarnya ditentukan oleh level referensialnya. Bagaimanapun, paling tidak menurut Barthes, narator dan karakter, pada dasarnya adalah 'tokoh-tokoh tulisan'; pengarang narasi (material) harus dibedakan dengan narator dari narasi tersebut (Barthes, 2010:111-112).

Selain itu, Wellek dan Warren (dalam Pradopo, 2011:76) membagi narator dalam dua jenis. Pertama, narator menceritakan pengalaman atau ceritanya sendiri, si pencerita menyebut tokoh utama sebagai aku. Adapun yang kedua, pencerita hanya berperan sebagai pelengkap, pencerita diceritakan sebagai 'saksi' terhadap cerita orang lain yang menjadi tokoh utama dalam kisah ini.

Ricoeur berpendapat bahwa struktur dalam kalimat mengacu balik kepada pembicara melalui prosedur gramatikal, yang oleh para linguis disebut dengan 'shifters'. Kata ganti orang, misalnya, tidak mempunyai makna objektif. 'Saya' bukanlah sebuah konsep. Tidaklah mungkin untuk menggantikannya dengan ekspresi universal seperti 'seorang yang sekarang sedang berbicara'. Fungsinya hanya memberikan 
acuan keseluruhan kalimat kepada subjek peristiwa pembicaraan. Ia akan memiliki makna yang baru setiap saat ia digunakan dan setiap saat ia mengacu pada subjek tunggal. 'Saya' adalah seseorang yang dalam pembicaraannya mengaplikasikan kata 'saya' bagi dirinya yang muncul dalam kalimat sebagai suatu subjek logis (Ricoeur, 2012: 39-40). Sedangkan menurut Widdowson (1997: 62), 'aku' dalam karya sastra, mengacu pada pemikiran pribadi, kesan, gambaran, dan persepsi pribadi orang tersebut sebagai individu. Namun, 'aku' yang dimaksud itu bukan penulis sebagai pengirim pesan, pakar yang terampil, 'si pembuat', tetapi batin yang dalam yang dijadikan obyek si penulis. Sehingga, dari kedua pernyataan tersebut terlihat bahwa narator atau 'aku' yang terdapat dalam cerita merupakan subjek logis yang bukan pengarang melainkan suatu subjek yang terdapat dalam teks linguistik.

Pernyataan Barthes tentang narator senada dengan penyataan Mieke Bal mengenai narator. Narator, menurut Mieke Bal tidak didefinisikan sebagai orang akan tetapi objek linguistik yang merepresentasikan cerita, seperti yang dikatakan Bal (1985:119) "I discuss the narrative agent, or narrator, I mean the linguistic subject, a function and not a person, which expresses itself in the language that constitutes the text. It hardly needs mentioning that this agent is not the (biographical) author of the narrative" (saya membicarakan pelaku narasi, atau narator, yang saya maksudkan adalah subjek linguistik, suatu fungsi, bukan orang, yang menyatakan dirinya dalam bahasa yang merupakan teks. Hampir tidak perlu untuk menyebutkan bahwa pelaku ini bukan penulis (biografi) dari narasi).

Berdasarkan kutipan di atas, sudah jelas terlihat bahwa yang dimaksudkan sebagai narator bukanlah tokoh atau orang (not a person), melainkan subjek yang terungkap lewat struktur linguistik teks, dalam hal ini cerita. Narator disini berfungsi sebagai subjek linguistik yang membawa pembaca masuk ke dalam cerita dalam suatu teks. Narator berperan sebagai penghubung antara teks dan pembaca, sehingga melalui narator pembaca dapat mengerti keberlangsungan cerita. Bal (1985:120) mengatakan bahwa "Narrator and focalization together determine what has been called narration - incorrectly, because only the narrator narrates, i.e. utters language which may be termed narrative since it represents a story." (Narator dan fokalisasi sama-sama menentukan apa yang disebut narasi (narration)-tidak benar, karena hanya narator yang bernarasi, yakni menuturkan bahasa yang disebut naratif karena merepresentasikan sebuah cerita. Sehingga, hanya narator-bukan fokalisatoryang dapat bernarasi, yaitu menuturkan bahasa secara naratif dan merepresentasikan sebuah cerita).

Mieke Bal membedakan narator menjadi dua jenis, yaitu narator eksternal dan narator intrernal. Hal ini berkembang berdasarkan istilah tentang pencerita orang pertama dan orang ketiga, namun istilah tersebut menurut Mieke Bal terasa tidak cocok, oleh karenanya Mieke Bal menggunakan istilah narator eksternal dan narator internal. Narator eksternal di sini dipahami sebagai narator yang berada di luar kisahan atau cerita, sedangkan narator internal dipahami sebagai narator yang terikat pada karakter atau tokoh dalam kisahan atau cerita. Sehingga, Mieke Bal menyimbolkan narator eksternal dengan (EN), sedangkan narator yang terikat dengan tokoh atau narator internal disimbolkan dengan $(\mathrm{CN})$.

Untuk memperjelas konsep eksternal narator serta internal narator $(\mathrm{CN})$, Bal (1985:122) memberikan contoh sebagai berikut:
a. I shall be twenty-one tomorrow.
b. Elizabeth will be twenty-one tomorrow. 
If what I said above is valid, we may rewrite both sentences as:

(I say:) I shall be twenty-one tomorrow. (I say:) Elizabeth will be twenty-one tomorrow.

(a. Saya akan berusia dua puluh satu tahun besok.

b. Elizabeth akan berusia dua puluh satu besok.

Jika apa yang dikatakan di atas valid, kita bisa menulis ulang kedua kalimat di atas sebagai berikut:

(Saya berkata:) Saya akan berusia dua puluh satu tahun besok.

(Saya berkata:) Elizabeth akan berusia dua puluh satu tahun besok.)

Kedua kalimat di atas dituturkan oleh objek pembicara yang sama yaitu 'I', namun yang membedakan kedua kalimat tersebut adalah objek tuturannya. Pada kalimat b. Pembicara atau pencerita membicarakan tentang dirinya, namun pada kalimat $\mathrm{c}$. Pencerita membicarakan tentang Elizabeth atau orang lain. Ketika di dalam sebuah teks, narator tidak secara nyata menunjukkan dirinya, ada kemungkinan bahwa kita berurusan dengan narator eksternal (EN). Sedangkan jika kita berhadapan dengan teks yang dinarasikan oleh 'I' yang menceritakan kisahnya sendiri, maka dapat dikatakan bahwa kita berurusan dengan pencerita yang terikat dengan tokoh (character-bound narator), atau seorang $\mathrm{CN}$.

\section{METODE PENELITIAN}

Penelitian merupakan penelitian kualitatif dan menggunakan metode penelitian deskriptif kualitatif. Penelitian kualitatif adalah penelitian yang dilakukan dengan tidak mengutamakan angka, tetapi mengutamakan kedalaman penghayatan terhadap interaksi antar konsep yang sedang dikaji secara empiris (Semi dalam Endraswara, 2011:5), seorang peneliti yang mengadakan penelitian kualitatif biasanya berorientasi pada orientasi teoretis
(Moleong, 1990:8). Metode penelitian menurut Faruk (2012:55) adalah cara untuk memperoleh pengetahuan mengenai objek tertentu dan, karenanya, harus sesuai dengan kodrat keberadaan objek itu sebagaimana yang dinyatakan oleh teori. Metode deskriptif kualitatif yaitu metode yang dilakukan dengan cara mendeskripsikan objek material yang akan diteliti secara kualitatif, kemudian disusul dengan analisis.

Dalam penelitian ini peneliti akan menggunakan metode deskriptif kualitatif. Objek kajian dalam hal ini narator novel Telegram akan dideskripsikan, kemudian beberapa fakta yang terdapat dalam objek kajian tersebut lalu dianalisis, dan nantinya akan menghasilkan temuan. Data dalam penelitian ini adalah teks novel Telegram yang dianggap merepresentasikan keberadaan narator. Sumber data dalam penelitian ini adalah novel Telegram karya Putu Wijaya dengan ketebalan 143 halaman, cetakan kedua yang diterbitkan oleh PT. Dunia Pustaka Utama pada tahun 1977. Teknik pengumpulan data dalam penelitian ini adalah teknik baca dan teknik catat. Adapun teknik analisis data dalam penelitian ini terdiri atas empat tahap yaitu; identifikasi narator, klasifikasi teks narator, analisis teks narator, dan deskripsi jenis-jenis narator tiap bab.

\section{PEMBAHASAN}

\section{Bab I}

Kalimat pertama pada bab pertama dalam novel Telegram dituturkan oleh tokoh Aku, seperti kutipan berikut:

(1) "AKU ada janji dengan Rosa. Sebagaimana biasa aku menganggap setiap perjumpaan dengannya adalah peristiwa resmi. Agar ia menjadi momen sejarah yang manis kelak, aku pun menyiapkan diriku dalam keadaan yang paling sip. Aku menghilangkan diriku dari segala macam profisi, untuk menjadi seorang kekasih, seorang lelaki 
dengan daging dan nyali jantan..."

(Wijaya, 1977:5)

Berdasarkan kutipan tersebut, maka tokoh Aku di sini berperan sebagai pencerita atau narator yang membawa masuk pembaca ke dalam kisah Aku yang akan bertemu dengan Rosa.

Pada bab I, tokoh Aku menceritakan tentang rencananya bertemu dengan Rosa. Hari itu merupakan hari pacaran tokoh Aku dan tokoh Rosa yang ketiga ribu dan tak lama lagi tokoh Aku dan tokoh Rosa akan menikah. Setelah berpacaran, tokoh Aku dan tokoh Rosa pun membicarakan tentang rencana pernikahan. Hal tersebut berdasarkan kutipan berikut:

(2) "Sudah kau fikirkan bahwa perkawinan ini berarti perubahan, perubahan pada diri kita?' tanyanya padaku.

'Aku mengerti dan aku sudah siap'

'Seandainya kelak ada yang hendak kau sesalkan, apa yang akan kau lakukan."'(Wijaya, 1977:6-7).

Cerita pun berlanjut pada persoalanpersoalan yang mungkin timbul jika tokoh Aku menikah dan pilihan yang dapat diambil jika ingin hidup bersama tanpa ikatan. Hal tersebut berdasarkan kutipan berikut:

(3) 'Maksudku' kataku meneruskan. 'Kita hidup bersama sebagai suami istri tanpa nikah resmi. Diam dulu, dengarkan. Ini berarti, dalam rumah tangga itu kita tetap menjadi kekasih. Lebih daripada itu, tak perlu kita pusing karena tetek bengek keluarga."” (Wijaya, 1977:9).

Ketika tokoh Aku mengantarkan tokoh Rosa pulang, tokoh Rosa mengatakan tokoh Aku dan tokoh Rosa tidak usah kawin saja jika tidak ingin berubah karena pernikahan. Namun, ketika mendengarkan perkataan tokoh Rosa, tiba-tiba, tokoh Sinta, anak pungut tokoh Aku sudah berdiri di dekat tokoh Aku dan mengajak tokoh Aku pulang ke rumah,sebab ada telegram. Hal tersebut berdasarkan kutipan berikut:

(4) "Aku tak bisa menangkap katakatanya, karena seseorang tiba-tiba menarik lengan bajuku. Waktu kutoleh, Sinta, anak pungutku yang berusia sepuluh tahun sudah berdiri di dekatku, sebagaimana biasanya, bila aku telat pulang... Sinta mendekatkan hidungnya ke mulutku, lalu tersenyum senang. 'Mari pulang Papa. Ada telegram.' "(Wijaya, 1977:13).

Jika dalam suatu cerita yang menuturkan cerita adalah tokoh yang secara gramatikal biasanya ia ditampilkan sebagai orang pertama ('Aku'), maka berdasarkan teori naratologi Bal, pencerita tokoh semacam itu disebut sebagai pencerita internal. Oleh karena itu, tokoh Aku merupakan pencerita atau narator internal.

Selain tokoh Aku, tokoh Rosa pun menjadi pencerita atau narator internal, namun, jika tokoh Aku yang membuka dan menutup cerita pada bab I sehingga tokoh Aku menjadi pencerita primer atau pencerita utama, maka tokoh Rosa di sini menjadi pencerita sekunder atau pencerita sampingan. Hal ini dikarenakan tokoh Rosa menarasikan pendapatnya dalam dialogdialog pada percakapannya dengan Aku, seperti kutipan berikut:

(5) "'Aku tak bisa membayangkan, kau, kau yang ku kenal sebagai sekarang ini, tiba-tiba berubah menjadi seorang, seorang bapak rumah tangga yang dingin, bijaksana, penuh tanggung jawab dan penyabar. Aku akan kehilangan kekasih, kau akan menjadi bapak anak-anak kita dan seorang suami pada umumnya, yang tak suka lagi memakai pakaian necis untuk istrinya. Seorang suami seperti umumnya yang cerewet dan sangat kritis pada kekurangan-kekurangan istrinya sebagai ibu rumah tangga. Begitu, bukan?"' (Wijaya, 1977:10).

\section{Bab II}

Pada bab II, kembali tokoh Aku yang membuka dan menutup cerita, seperti kutipan berikut: 
(6) "AKU memerlukan meneguk segelas bir, sebelum telegram itu kubuka. Ini kebiasaan yang kuperoleh setelah banyak surat yang kuterima isinya malapetaka. Salahku juga. Aku menganggap surat-menyurat barang sepele. Jadi dari pihak pengirim-pengirim surat ada kebiasaan: hanya hal-hal luar biasa saja yang pantas diabadikan dalam sebuah surat. Teristimewa telegram..." (Wijaya, 1977:14).

(7) "Aku membacanya kembali untuk diriku:

IBU MENINGGAL CEPAT PULANG TITIK

Aku melipatnya dengan hati-hati, seperti juga waktu aku melipat telegram kematian ayah. Lonceng itu menggeram lagi untuk kedua kalinya dalam pengetahuanku. Satu kali." (Wijaya, 1977:26)

Sehingga, kembali tokoh Aku yang menjadi narator pada bab II.

Bab II pada novel Telegram ini, menceritakan tentang telegram yang diterima tokoh Aku. Telegram tersebut mengabarkan tentang kematian ibu tokoh Aku. Tokoh Aku kemudian menulis surat balasan untuk saudara tirinya yang berada di Bali, dan setelah menulis versi ketiga surat tersebut, tokoh Sinta menanyakan tentang isi telegram yang diterima tokoh Aku.

(8) '“'Papa, apa isi telegram itu?' tanya Sinta dari kamar.

Aku baru tahu anak itu ternyata ikut gelisah juga. Ini kebiasaan lagi. Ia sudah terbiasa dalam situasi tertekan apabila aku menerima surat, maklum selalu ada hal-hal yang luar biasa. Surat, telegram, kabar apa pun namanya yang sebangsa itu, rupanya sudah menjadi simbol malapetaka di rumahku." (Wijaya, 1977:19).

Tokoh Aku berbohong dan mengatakan bahwa ia harus menjemput seseorang di stasiun Gambir besok. Tokoh Aku kemudian melihat tokoh Sinta yang hampir menangis dan kemudian bertanya pada tokoh Sinta mengapa ia menangis, dan tokoh Sinta kemudian menjelaskan kekhawatirannya pada tokoh Aku. Hal tersebut berdasarkan kutipan berikut:

(9) “' Sinta tak mau ditinggal lagi. Susah kalau tidak ada Papa. Semua orang sok tahu. Mengurus rumah tak becus. Maunya sendiri saja. Sok marah-marah lagi.' Gerutunya barangkali ingat pembantu yang mengasuhnya tatkala kutinggal pulang karena ayah meninggal."” (Wijaya, 1977:22-23).

Setelah tokoh Sinta tenang, tokoh Aku menanyakan tanggapan tokoh Sinta jika suatu saat tokoh Aku ingin menikah. Ketika tokoh Sinta tidak merespons maka tokoh Aku menjelaskan kemungkinankemungkinan yang akan terjadi jika tokoh Aku menikah,dan setelah menjelaskan hal tersebut tokoh $\mathrm{Aku}$ menyuruh tokoh Sinta kembali tidur.

Pada bab II, yang menjadi narator utama adalah tokoh Aku. Selain tokoh Aku, tokoh Sinta pada bab ini berperan sebagai narator sekunder atau pencerita sampingan, hal ini disebabkan oleh tokoh Sinta menceritakan kecemasannya tentang kemungkinan tokoh Aku akan meninggalkan tokoh Sinta untuk pulang ke Bali karena ibu tokoh Aku meninggal.

\section{Bab III}

Bab III pada novel Telegram menceritakan tentang pertemuan tokoh Aku dan tokoh Nurma, seorang PSK. Tokoh Aku menceritakan pada tokoh Nurma bahwa ia akan pulang ke Bali untuk sementara waktu. Tokoh Nurma kemudian mengajak tokoh Aku untuk menikah, dan tokoh Aku berjanji akan hidup bersama tokoh Nurma jika nanti ia kembali ke Jakarta. Hal tersebut berdasarkan kutipan berikut:

(10)“' Ayo kawin.'

Aku tersenyum, karena caranya mengucapkan.

'Ayo!'

'kontraklah rumah.'

'di mana?' 


$$
\begin{aligned}
& \text { 'di Tanjung Periuk ada yang } \\
& \text { murah. Di sini juga } \\
& \text { ada!'...(Wijaya, 1977: } 34 \text { ) }
\end{aligned}
$$

Kemudian, setelah berpisah dengan tokoh Nurma, tokoh Aku bertemu teman kantornya, dan teman tokoh Aku tersebut mengajak tokoh Aku nongkrong di warung kopi sampai pagi. Hal tersebut terlihat dalam kutipan berikut:

(11)“'Bagaimana kalau kita ngopi sampai pagi di sini? Lalu pulang ke rumahmu, sehingga aku bisa menyucikan semua kejahatan ini. Dan kau harus memperkuat pertanggung jawabanku kepada istriku. Bilang saja ...'

Aku setuju. Aku jadi teringat apa yang sudah diucapkannya di kantor ..." (Wijaya, 1977: 36)

Teman tokoh Aku tersebut bercerita tentang ketakutannya apabila pemuja-pemujanya yang selama ini memitoskannya sebagai orang saleh tiba-tiba mengetahui bahwa ia sering ke daerah lokalisasi. Tokoh Aku hanya mendengarkan perkataan temannya tersebut hingga ia tertidur, waktu terbangun dilihatnya temannya tersebut sedang tertidur pula di bangku tukang kopi, dan tokoh Aku pun pulang ke rumah. Hal tersebut berdasarkan kutipan berikut:

(12)"Kutinggalkan saja dia bergulat dengan dirinya.

Pulang.

Sinta seperti menangis waktu kujenguk ke kamarnya. Ia masih pulas. Bisa jadi pura-pura. Ya Tuhan, berartinya tempat tidur itu. Ia memeluk, menenggelamkan aku. Hidup seperti berakhir sudah." (Wijaya, 1977:39).

Jika pada bab I dan bab II yang menuturkan cerita adalah tokoh Aku, maka pada bab III ini, yang membuka cerita adalah narator eksternal. Hal tersebut berdasarkan kutipan berikut:

(13)“'Seorang redaktur hukum sebuah majalah berkata 'Kabut di seluruh Sumatera, sehingga kapal terbang tak bisa mendarat. Musim kemarau yang panjang dan akan semakin mengerikan lagi tahun depan, akibat ledakan matahari. Hargaharga bahan pokok naik ...' " (Wijaya, 1977:27).

Pada kalimat tersebut, tidak diketahui identitas siapa yang menjadi pencerita atau narator, sehingga dapat diasumsikan bahwa yang menjadi pencerita pada kalimat pembukaan pada bab III adalah seorang narator eksternal, seorang narator yang tidak terlibat dalam cerita. Tugas narator eksternal tersebut hanya mengantarkan pembaca memasuki cerita tanpa terlibat dalam cerita. Namun, pada baris ke 71 tokoh Aku mengatakan bahwa kejadian yang berupa perdebatan tentang usulan cover story pada awal cerita merupakan kejadian lampau yang terjadi di tempat kerja tokoh Aku. Hal tersebut berdasarkan kutipan berikut:

(14)“'Itu semua belum lama terjadi di tempat pekerjaanku. Aku mengingatnya, karena Aku merasa sangat kerdil, karena justru saat itu aku sedang memikirkan persoalan remeh yang sangat klise: bagaimana mengurangi rasa cemas. Aku malu karena tak ikut berfikir tentang masalah dunia dan manusia pada umumnya "... (Wijaya, 1977:29).

Sehingga, berdasarkan kutipan di atas, terlihat perpindahan cerita dari cerita masa lampau ke cerita masa kini, yang dimaksudkan dengan cerita masa kini adalah cerita tentang pertemuan tokoh Aku dengan tokoh Nurma serta pertemuan tokoh Aku dan teman kantornya di daerah lokalisasi.

Jika yang membuka cerita pada bab III adalah narator eksternal, maka yang menutup cerita adalah narator internal yaitu tokoh Aku, seperti kutipan berikut:

(15)"Pulang.

Sinta seperti menangis waktu kujenguk ke kamarnya. Ia masih pulas. Bisa jadi pura-pura.Ya Tuhan, berartinya tempat tidur itu. Ia memeluk, 
menenggelamkan aku. Hidup seperti berakhir sudah". (Wijaya, 1977:39).

Dalam bab ini terdapat dua narator, yaitu narator eksternal pada permulaan cerita dan narator internal. Perpindahan dari narator eksternal ke narator internal terjadi pada saat peralihan dari cerita lampau ke cerita masa kini.

Selain tokoh Aku, teman tokoh Aku juga termasuk narator internal, sebab ia juga menarasikan pendapatnya. Ia menjadi pencerita pada saat tokoh Aku dan dia berada di warung kopi. Hal ini menjadikannya narator internal pada tataran ke dua atau pencerita kedua.

\section{Bab IV}

Pada bab IV, tokoh Aku kembali membuka dan menutup cerita. Hal tersebut berdasarkan kutipan berikut:

(16)“AKU mimpi bersanggama dengan ibu. Ini untuk kesekian kalinya. Tetapi karena kini ibu sudah meninggal, aku berusaha menolak mimpi itu. Ia berkelanjutan juga dengan semena-mena. Untung saja aku segera tersadar. Ternyata malam masih bersisa. Aku memandangnya lewat jendela dengan hati yang masih belum pasti arahnya ..." (Wijaya, 1977:40).

(17)“Bagaimana mereka bisa berkumpul begitu.

Aku merasa malang sekali. Untunglah aku segera dapat menginsafkan diri bahwa semuanya itu hanya mimpi. Omong kosong. Lelucon. Permainan batin yang capek. Terhibur juga." (Wijaya, 1977:45).

Yang menjadi narator dalam bab IV adalah tokoh Aku. Karena tokoh Aku merupakan tokoh dalam cerita tersebut, kedudukan tokoh Aku di sini adalah sebagai narator internal.

Bab IV menceritakan tentang teman tokoh Aku yang datang ke rumahnya dan menumpahkan segala keluh kesah tentang keluarganya. Setelah teman tokoh Aku selesai membentangkan pendapatpendapatnya, tokoh Aku kemudian mengajak temannya berjalan-jalan. Mereka pun naik becak tanpa tujuan, kemudian ketika hujan turun mereka pun berjalanjalan. Cerita pada bab ini kemudian berlanjut pada kisah tentang tokoh Aku dan temannya yang kemudian membantu anak-anak jalanan mendorong mobil yang sedang mogok karena hujan. Hal tersebut berdasarkan kutipan berikut:

(18) “'Ini peristiwa bersejarah,' kata kawanku. 'setiap saat kita bisa lagi menjadi kanak-kanak kalau kita mau. Ayo kita bantu mendorong!'

Ia lantas berlari menggabungkan diri dengan anak-anak itu. Aku melonjak ikut ..." (Wijaya, 1977:42).

Cerita kemudian berlanjut pada kisah tentang tokoh Aku yang mendapat bayaran dari mendorong mobil. Tokoh Aku kemudian membelanjakan uang yang didapatkannya. Setelah itu, teman tokoh Aku menyarankan agar melepas semua pakaian mereka, seperti yang terlihat dalam kutipan berikut:

(19)"Kami pun membuka semuanya. Memeras. Lalu rasanya kami sudah bersatu dengan kaki lima itu. Perasaan risi yang biasanya ada, tiba-tiba tanggal saja. Sambil mengunyah balok dan meneguk sekoteng yang pedas, aku mendapati hujan tidak lagi segetir biasanya ..." (Wijaya, 1977:44).

Kemudian tokoh Aku mendapati dirinya telah tertidur di pinggir jalan, ada yang melarikan semua pakaian tokoh Aku yang telah dilepasnya. Maka, tokoh Aku 
berusaha pulang agar tidak ada yang melihatnya dalam keadaan telanjang, namun tokoh Aku kemudian terjatuh ke sungai dan mendapati temannya juga berada di sana, dan di pinggir sungai telah banyak orang yang memandang tokoh Aku termasuk tokoh Sinta dan tokoh Rosa. Namun, ia akhirnya dapat menyadarkan dirinya bahwa semua kejadian barusan adalah mimpi. Hal tersebut terlihat dalam kutipan berikut:

(20)“Aku merasa malang sekali. Untunglah aku segera dapat menginsafkan diri bahwa semuanya itu hanya mimpi. Omong kosong. Lelucon. Permainan bathin yang capek. Terhibur juga." (Wijaya, 1977:45).

Narator yang membuka dan menutup cerita pada bab ini adalah tokoh Aku. Namun, yang memegang peranan penting dalam alur cerita adalah teman tokoh Aku. Hal ini disebabkan karena teman tokoh Akulah yang memberikan saran-saran pada tokoh Aku sehingga cerita tersebut berlanjut berdasarkan arahan teman tokoh Aku. Tokoh Aku merupakan narator pada bab ini, namun karena temannya memiliki peranan penting dalam menentukan jalannya cerita maka teman tokoh $\mathrm{Aku}$ ini menjadi narator sampingan atau pencerita sekunder. Teman tokoh Aku tidak menjadi pencerita kedua sebab ia tidak menarasikan kisahnya, tetapi teman tokoh Aku ini membantu mengatur jalannya cerita, seperti yang terlihat dalam kutipan berikut:

(21)“SSahabatku mengusulkan bagaimana kalu berhujan-hujan. 'Waktu kecil kita menikmati hujan itu. Mengapa sekarang tidak?'

Setelah didesak keras, akhirnya aku setuju juga. Kami berhujanhujan..." (Wijaya, 1977:42).

(22)“'Ia lantas berlari menggabungkan diri dengan anak-anak itu. Aku melonjak ikut. Kami dorong suburban itu.
Merasa diri sebagai anak-anak, melupakan segala yang baru saja difikirkan, kami ikut berteriak, mengumpat dan memberi instruksi-instruksi..." (Wijaya, 1977: 42-43).

(23) "'Tanggalkan semuanya. Di sini tidak ada malu-malu, bukan begitu Bang?' tanya kawanku pada tukang sekoteng. 'pakaian basah bisa membuat sakit perut' jawab pedagang itu. Kami pun membuka semuanya..." (Wijaya, 1977:44).

\section{Bab V}

Bab V pada novel Telegram bercerita tentang rencana tokoh Aku dan tokoh Sinta yang akan pergi ke stasiun. Hal tersebut berdasarkan kutipan berikut:

(24)“AKU bangun kasip. Sinta sudah menunggu. Ia telah siapsiap untuk pergi ke stasiun. Kopi yang disiapkannya telah dingin. Dengan agak malu aku meneguknya sambil menyelidik apa yang akan kulakukan. Saat untuk menikmati keadaan tidak bersikap telah berangkat. Kini setiap perbuatan dituntut untuk berarti." (Wijaya, 1977: 46).

Tokoh Aku dan tokoh Sinta kemudian berangkat ke stasiun. Di sana, tokoh Aku dan tokoh Sinta menunggu, dan karena bosan menunggu, akhirnya tokoh Sinta memutuskan berjalan-jalan. Ia kemudian memasuki sebuah kios majalah dan membeli sebuah majalah, kemudian tokoh Sinta lalu duduk di sebuah kursi stasiun. Hal-hal tersebut di atas berdasarkan kutipan berikut:

(25)"'Sinta bilang mau jalan-jalan.

Tidak kutemani, ia cukup dapat menguasai dirinya. Di samping itu tampaknya memang butuh. Aku tak pernah berkhayal yang bukan-bukan tentang dirinya. Misalnya, kalau-kalau ia diculik. Anak yang bertingkah seperti 
orang dewasa itu sudah terlindung oleh sikapnya ..." (Wijaya, 1977:48).

(26)"Ia berjalan menyusur tepi stasiun. Mula-mula ia tertarik pada buku-buku yang dijual di dalam kios. Ia memang gemar membaca, karena hanya itu yang merupakan hiburannya. Kulihat ia menawar sesuatu. Membayar. Tenyata majalah Femina. Sebuah majalah untuk para ibu. Tidak. Majalah Intisari." (Wijaya, 1977:48).

Di samping tokoh Sinta, duduk sebuah keluarga besar yang sedang mengadakan perjalanan. Tokoh Sinta memerhatikan keluarga tersebut, keluarga tersebut memiliki sepuluh orang anak, dan seorang anak mulai mengganggu tokoh Sinta dengan tulang ayam yang sedang dipegangnya, namun ketika tokoh Sinta menghindar, anak nakal tersebut mengejar dan melempari tokoh Sinta dengan tulang ayam. Hal tersebut berdasarkan kutipan berikut:

(27)“'Salah seorang anak, tampaknya yang paling bandel, diam-diam melemparkan tulang ayam pada Sinta. Tatkala Sinta menoleh padanya dengan pandangan tidak mengerti, dua anak dari kumpulan itu mencibirkan bibir. Sinta tidak membalas. Ia menghindar, tetapi tetap tidak melepaskan perhatiannya..." (Wijaya, 1977:49).

Tokoh Aku kemudian menghampiri tokoh Sinta dan anak nakal tersebut menjadi takut dan kembali ke keluarganya. Ketika kereta yang ditunggu tokoh Aku sudah datang, tokoh Aku kemudian berdiri dan ikut menunggu dengan orang-orang lain yang juga sedang menunggu, dan ketika kereta tersebut sedang berangkat lagi, tokoh Sinta sedang sibuk membaca majalah yang tadi dibelinya. Tokoh Aku mengambil majalah yang sedang dibaca tokoh Sinta dan ternyata dibalik majalah yang dibacanya terdapat majalah dewasa. Tokoh Aku memarahi tokoh Sinta, kemudian tokoh Sinta menyerahkan telegram yang semalam terjatuh dari kantong celana tokoh Aku. Ternyata tokoh Sinta sudah mengetahui isi telegram yang diterima tokoh Aku kemarin yang mengabarkan bahwa ibu tokoh Aku sakit keras, sehingga ia harus pulang ke Bali. Tokoh Sinta kemudian mengajak tokoh Aku pulang ke rumah sebab badan tokoh Aku terasa panas, seperti yang terlihat pada kutipan berikut:

(28)"Sinta merogoh sesuatu dari sakunya. Ia mengeluarkan segumpal kertas dan uang kecil. 'Ini punya Papa. Sinta pungut di lantai waktu Papa pergi tadi malam'

Kusambut barang-barang yang kuduga dicopet tukang rokok itu. Dengan agak terkejut, karena di antaranya ada juga telegram semalam. Rupanya aku benar-benar mabok semalam." (Wijaya, 1977:52).

(29)"kupegang tangan Sinta. Kuletakkan di tengkukku. Sinta terperanjat.

'Papa sakit?'

'Ya!'

'Ayo pulang, Pa!' " (Wijaya, 1977:53).

Kalimat pertama dalam bab $\mathrm{V}$ pada novel Telegram ini dibuka dan ditutup dengan penuturan tokoh $\mathrm{Aku}$, hal ini menjadikan tokoh Aku kembali menjadi narator internal pada bab ini. Hal tersebut berdasarkan kutipan berikut:

(30)“AKU bangun kasip.Sinta sudah menunggu. Ia telah siap-siap untuk pergi ke stasiun. Kopi yang disiapkannya telah dingin. Dengan agak malu aku meneguknya sambil menyelidik apa yang akan kulakukan. Saat untuk menikmati keadaan tidak bersikap telah berangkat. Kini 
setiap perbuatan dituntut untuk berarti." (Wijaya, 1977:46).

(31)“Di dalam helicak yang mengatar kami pulang, aku menerbitkan telegram itu kembali. Walaupun dengan perasaan yang tetap tidak enak. Isinya kami baca bersama-sama: IBU SAKIT KERAS CEPAT PULANG TITIK

Sinta menyandarkan kepalanya ke sisiku. Ia menahan tangisnya." (Wijaya, 1977:53).

\section{Bab VI}

Bab VI pada novel Telegram ini berkisah tentang tokoh Aku yang pergi memeriksakan dirinya ke dokter. Hal tersebut terlihat pada kutipan berikut:

(32)"Pukul dua kurang, aku sampai di rumah praktek dokter Go yang telah merubah namanya jadi Goenawan. Ia selalu praktek tengah hari. Siang itu banyak yang periksa sehingga aku terpaksa melewatkan waktu dengan Max Tua tukang parkir. Ia sudah lupa padaku, tetapi pura-pura saja ingat..." (Wijaya, 1977:54).

Setelah memeriksakan dirinya ke dokter, tokoh Aku kemudian ke apotek untuk menebus obatnya, dan ketika melihat bahwa obat yang didapatkannya hanya pel, tokoh Aku menjadi ragu untuk meminumnya. Namun, akhirnya tokoh Aku meminum obat tersebut dan kemudian tokoh Aku pergi ke kantor. Hal tersebut terlihat dalam kutipan berikut:

(33)“Aku kecewa sekali setelah mengetahui tidak mendapat kapsul. Memang ada tiga macam pel, tetapi terasa tidak meyakinkan karena semuanya hanya berharga tidak lebih dari lima ratus rupiah. Biasanya resep dokter paling tidak berharga dua ribu. Meskipun ini berarti penyakitku tidak serius, kepercayaan pada kapsul dan antibiotica menyebabkan aku menelan pel itu dengan raguragu ..." (Wijaya, 1977:57).

Di kantor, tokoh Pak Tua yang merupakan pesuruh kantor, datang menghampiri dan memberitahukan pada tokoh Aku bahwa ada tamu yang menunggunya, namun tokoh Aku tak ingin menemui tamu tersebut sehingga ia memutuskan tidak menerima tamu tersebut dan pergi beristirahat di rumah sahabatnya yaitu Zen. Hal tersebut berdasarkan kutipan berikut:

(34)"Sebuah oplet kemudian menolongku pergi dari kantor. Pergi ke rumah sahabatku Zen. Hari sudah lewat pukul tiga. Panas sekali. Tengkukku rasanya bertambah panas. Tamu. Mereka sama mengganggunya dengan surat. Beberapa tahun di Jakarta ini, aku selalu menghindar kalau menerima tamu, baik sahabat lama atau famili..." (Wijaya, 1977:59).

Narator pada bab ini adalah tokoh Aku, sehingga tokoh Aku kembali menjadi narator internal pada bab ini. Hal tersebut berdasarkan kutipan berikut:

(35)"Masih ada sisa siang untuk pergi ke dokter. Kupesankan pada Sinta agar tidak meninggalkan rumah. Ada kemungkinan aku akan kerja lembur setelah berobat. Apa pun yang terjadi, meskipun ibu hanya sakit keras, pulang sudah harus pasti. Dalam dua atau tiga hari mendatang aku mungkin bisa menyelesaikan pekerjaan untuk dua minggu mendatang..." (Wijaya, 1977:54).

(36) "Aku mendapat kesempatan berdiam diri dalam oplet itu, tanpa diusik pertanyaan dari sekitar. Kupikir-pikir ini 
agaknya yang menyebabkan aku suka mengadakan perjalanan sendirian. Betapa menakjubkannya kalau tiba-tiba teringat bahwa seringkali kalimat-kalimat itu telah melompat dari mulut kita seperti katak, tanpa kita kehendaki sendiri. Ia telah hidup bebas dan bermain-main dengan rongga mulut kita yang tidak bisa lagi dikatupkan.” (Wijaya, 1977:60).

\section{Bab VII}

Bab VII pada novel ini bercerita tentang tokoh Aku yang setelah beristirahat sejenak di rumah sahabatnya memutuskan kembali ke kantornya, seperti yang terlihat dalam kutipan berikut:

(37)"Pukul enam aku bangun.

Seluruh tubuh rasanya seperti

barusan dilindas stoom. Zen

belum pulang. Istrinya ke

dokter. Aku segera

membereskan diriku. Kulakukan

beberapa gerakan Orhiba. Otot-

otot yang kaku mau tambah

kendor sedikit. Tanpa mandi

atau cuci muka, aku berangkat

lagi ke kantor. Aku harus

menyelesaikan cover story

tentang Bali." (Wijaya, 1977:61).

Setibanya di kantor, tokoh Aku mendapati titipan berserta surat dari ibunya. Setelah membaca surat tersebut, tokoh Pak Tua kemudian bertanya tentang isi surat tersebut dan tokoh Aku hanya mengatakan bahwa ibunya sakit. Akan tetapi, tiba-tiba tokoh Pak Tua menceritakan riwayat hidupnya, seperti yang terlihat pada kutipan berikut:

(38)"Ia tak bertanya lagi. Ia mulai menyapu. Tetapi tiba-tiba saja ia mulai menceritakan kehidupan keluarganya sendiri. Tak paham aku apa maksudnya. Entah ingin mengemukakan bahwa aku tidak cukup malang dibandingkan

nasibnya, atau sekedar mengalihkan pikiran saja..."

(Wijaya, 1977:65).

Tokoh Aku tak terlalu memperhatikan cerita kehidupan tokoh Pak Tua, tokoh Aku hanya mengenang kenangan masa lalu di Bali. Tiba-tiba terdengar sirene pemadam kebakaran tak jauh dari kantor tokoh Aku, dan lamunan tokoh Aku pun terhenti. Kemudian tokoh Pak Tua datang untuk menawarkan kopi, tapi tokoh Aku menolaknya dan tokoh Pak Tua akhirnya pergi. Hal tersebut berdasarkan kutipan berikut:

(39)“Aku tak menjawab. Kadangkadang si Tua itu bangkit hasratnya untuk melucu. Ia tahu juga aku tak suka diganggu. Untuk tidak meninggalkan dosa, ia mengeluarkan rokoknya.

'Mau!'

Kutolak. Orang tua itu turun. Aku sendirian kembali." (Wijaya, 1977:68).

Pada bab VII ini yang menjadi narator adalah tokoh Aku. Tokoh Aku kembali menarasikan awal hingga akhir cerita, sehingga tokoh Aku di sini kembali menjadi narator internal pada bab ini.

\section{Bab VIII}

Pada bab VIII ini, tokoh Aku menceritakan keadaan dirinya, tokoh Aku merasa dirinya seperti memasuki kematian. Hal tersebut berdasarkan kutipan berikut:

(40)"RASANYA seperti memasuki kematian. Listrik mati, semua orang sudah tidur. Aku merasa sendirian yang masih hidup. Dari lubang ventilasi yang tinggi itu menggelinding angin menggoyangkan kalender di meja sebelah. Tengkukku seperti terbakar rasanya." (Wijaya, 1977:69)

Akibat suhu badan yang sangat panas, tokoh Aku mulai mengkhayalkan kematian 
dirinya, dilihatnya beberapa wajah orang yang sudah mati muncul di hadapan tokoh $\mathrm{Aku}$, mereka memanggil tokoh Aku untuk bergabung dengan mereka namun tokoh Aku menolaknya. Hal tersebut berdasarkan kutipan berikut:

(41)"Mereka mulai berbisik-bisik. Ada yang ngajak, ada lagi yang mempersilahkan. Aku tak mau. Kulawan hati untuk mengatakan ya. Supaya mereka lega, kupanjatkan untuk mereka doa agar mendapat tempat yang layak di mana saja mereka berada sekarang..." (Wijaya, 1977:70).

Kemudian tokoh Aku naik ke ruang redaksi. Di ruang tersebut tokoh Aku melakukan gerakan orhiba, dan setelah itu tokoh Aku kemudian membayangkan melakukan onani dengan model kalender yang terdapat di atas meja redaktur. Akan tetapi, tokoh Aku tidak dapat berkonsentrasi akibat suhu badannya yang panas, sehingga khayalannya pun tak berhasil. Tokoh Aku kemudian pergi ke ruang perpustakaan dan menimbun dirinya dengan tumpukan majalah, setelah itu tokoh Aku mengangkat telepon yang berdering, dan kemudian tokoh Aku kembali turun ke ruang bawah. Berdasarkan ringkasan cerita tersebut Tokoh Aku pada bab ini kembali menjadi narator internal yang menceritakan kisahnya.

\section{Bab IX}

Bab IX pada novel Telegram bercerita tentang kondisi tokoh Aku yang semakin memburuk, di seluruh tubuhnya muncul bintik-bintik merah. Hal tersebut berdasarkan kutipan berikut:

(42)"PAGINYA kuketahui bahwa seluruh tubuhku penuh bintikbintik merah. Orang tua penjaga kantor itu mengamat-amati tubuhku dengan penuh perhatian. Disuruhnya aku menanggalkan baju. Ia menggeleng-gelengkan kepalanya dengan tenang."

(Wijaya, 1977:78).

Tokoh Aku kemudian memutuskan untuk pulang ke rumah dan menunggu sore tiba sehingga ia dapat pergi ke dokter kenalannya. Ketika tokoh Aku tiba di rumah, ia melarang Sinta mendekat dan menyuruh Sinta dan bibi menyiapkan air panas dan bubur, dan setelah makan sedikit tokoh Aku tertidur. Ketika tokoh Aku bangun kembali hari masih siang, dan karena merasa kesepian, tokoh Aku menyuruh tokoh Sinta dan bibi berbincang-bincang di dekatnya agar tak sepi, namun ketika tokoh Sinta dan bibi membicarakan masalah keluarga bibi, tokoh Aku menjadi tidak senang dan menyuruh mereka berhenti membicarakan kesulitan rumah tangga bibi. Hal tersebut berdasarkan kutipan berikut:

(43)"Bibi kemudian membicarakan kesulitan rumah tangganya. Aku tak suka mendengar.

'jangan ceritakan kesulitan itu lagi!' teriakku. 'cerita yang lain!'

Untuk beberapa lama keduanya terdiam. Sinta kemudian ngajak bibi bercakap-cakap tentang kawan-kawannya di sekolah..." (Wijaya, 1977:82).

Kemudian ketika siang hari, tokoh Sinta datang dan menghampiri tokoh Aku dengan membawa akte kelahiran. Hal tersebut berdasarkan kutipan berikut:

(44)“'Sinta menunjukkan selembar kertas. Mula-mula aku hanya mengawasi. Tiba-tiba aku tersirap. Itu akte kelahiran Sinta. 'Lho, dapat dari mana!'

'Di tumpukan buku, waktu Sinta bongkar-bongkar tasi malam' Sinta mengulurkannya kepadaku, kusambut cepat, lalu kusuruh kembali ia menjauh..." (Wijaya, 1977:83).

Akte kelahiran tersebut adalah akta kelahiran tokoh Sinta yang di dalamnya tertulis bahwa tokoh Sinta adalah anak tokoh 
Aku dengan seorang perempuan yang bernama Rosa. tokoh Sinta ingin menanyakan tentang akte kelahiran tersebut, tapi akhirnya tokoh Sinta menunda menanyakan hal tersebut. tokoh Aku melewatkan waktu menunggu sore dengan mengarang penjelasan yang akan diceritakannya nanti pada tokoh Sinta. Hal tersebut berdasarkan kutipan berikut:

(45)“Aku menunggu. Tak ada apaapa yang teradi. Sedang di tanganku, akte kelahiran yang kudapatkan dengan nyogok pegawai pencatatan sipil itu, dapat sekedar mengalihkan pikiranku dari kecemasan. Aku memang belum benar-benar siap untuk mati, karena banyak soal yang masih perlu dibereskan. (Wijaya, 1977:84).

Cerita pada bab IX ini dituturkan oleh tokoh Aku, sehingga tokoh Aku pada bab ini menjadi narator internal sebab dari awal hingga akhir cerita, tokoh Aku yang menarasikan cerita.

\section{Bab X}

Cerita pada bab $X$ dalam novel Telegram dibuka dan ditutup oleh penuturan tokoh Aku, sehingga narator pada bab X dalam novel Telegram ini adalah tokoh Aku, seperti kutipan berikut:

(46)"Dokter Syubah, menghidupkan aku kembali. Setelah memeriksa bintik-bintik yang misterius itu, ia hanya menyangka aku kena alergi. Barangkali obat dokter Goenawan terlalu serampangan. Syubah memberikan aku kapsul berwarna merah hitam, pel merah untuk menurunkan panas dan incidal yang kecil-kecil lucu bentuknya..." 1977:85).

(Wijaya,

Tokoh Aku kembali yang menjadi narator internal pada bab ini. Setelah dari dokter, tokoh Aku kemudian pulang ke rumah dan beristirahat. Hal tersebut terlihat pada kutipan berikut:

(47)“Seperti yang diramalkan oleh dokter, aku tertidur cepat. Aku terlena sebelum sempat menceritakan apa-apa. Sinta menggugah supaya aku pindah ke kamar.

Aku benar-benar tidur. Seperti menebus utang.

Aku mimpi bertemu dengan presiden

Selintas kulihat: pagi melangkahiku." (Wijaya, 1977:86).

Kemudian ketika tokoh Aku, terbangun hari telah sore, dan saat malam tiba, tokoh Aku bercerita tentang Rosa, nama ibu palsu dalam akte kelahiran tokoh Sinta. Tokoh Aku berbohong tentang identitas tokoh Sinta yang sebenarnya. Sesungguhnya, ibu tokoh Sinta masih memiliki hubungan keluarga dengan tokoh Aku, ketika masih sekolah, ibu Sinta hamil di luar nikah dengan teman sekolahnya. Hal tersebut berdasarkan kutipan berikut:

(48)“Aku sendiri mulai memutuskan dalam hati untuk berbohong demi kebaikan. Sebab aku sendiri tak bisa membayangkan kalau tiba-tiba anak itu merubah sikapnya kepadaku, kalau ia tahu aku bukan apa-apanya. Aku hanya seorang lewat yang kebetulan ingin melampiaskan dendamku yang tidak habishabisnya pada, pada segala sesuatu yang bersifat, bersifat mau mendesak orang. Ibu Sinta masih bertaut famili denganku..." (Wijaya, 1977:88).

Setelah tokoh Aku berbicara tentang identitas nama ibu yang berada di akte kelahiran tokoh Sinta, ia pergi ke kamarnya dan kembali dengan membawa sebuah surat. Melihat surat tersebut tokoh Aku jadi curiga bahwa ibu kandung Sinta yang mengirimnya. Tetapi ketika tokoh Aku 
menanyakan surat tersebut, tokoh Sinta kemudian menangis. Tokoh Aku kemudian membuka dan membaca surat tersebut. Ternyata surat tersebut surat dari guru tokoh Sinta di sekolah, ia menyatakan cintanya pada tokoh Sinta. Setelah membaca surat tersebut, tokoh Aku kemudian mendongeng panjang tentang cinta, seperti yang terlihat dalam kutipan berikut:

$$
\begin{aligned}
& \text { (49)“'Sinta' kataku sambil } \\
& \text { mencari-cari apa yang harus } \\
& \text { kulakukan. } \\
& \text { 'Sinta, tenanglah. Cinta } \\
& \text { adalah semacam...' } \\
& \text { Aku mendongeng panjang. } \\
& \text { Kukira juga aku sedang } \\
& \text { merumuskan pendapat- } \\
& \text { pendapat untuk menenangkan } \\
& \text { hatiku sendiri." (Wijaya, } \\
& \text { 1977:93). }
\end{aligned}
$$

\section{Bab XI}

Kalimat pertama dalam bab XI ini dinarasikan oleh tokoh Aku. Hal tersebut kutipan berikut:

(50)“'BILA Waktu Menjamah Bali' artikel panjang yang direncanakan itu dapat kumulai dengan baik esok harinya. Pukul enam aku sudah berada di kantor. Sebelum tukang sapu membangunkan debu, aku sudah selesai menyusun angka-angka data dan menyelusupkannya dalam bagian permulaan laporan. Angka-angka itu cukup menunjukkan bahwa kampanye penjualan Bali memang benarbenar sedang diusahakan..." (Wijaya, 1977:94).

Tokoh Aku kemudian menarasikan peristiwa-peristiwa yang dialaminya, dimulai dari mengumpulkan data-data yang mendukung artikelnya, meminta izin pada atasanya untuk pulang, menyelesaikan artikel yang harus dibuatnya, membereskan barang-barang di mejanya, kemudian datang teman tokoh Aku yang mengabarkan perkawinannya pada tokoh Aku, tokoh Aku melanjutkan kembali membereskan mejanya, dan peristiwa terakhir yaitu datangnya tokoh Pak Tua yang mengabarkan pada tokoh Aku bahwa ada tamu yang menunggunya. Sehingga, pada bab ini tokoh Aku kembali menjadi narator internal.

\section{PENUTUP}

Dari 11 bab dalam novel ini, yang menjadi narator atau pencerita utama dalam setiap bab adalah tokoh Aku. Berdasarkan teori naratologi Mieke Bal, jika pencerita menampakkan dirinya sebagai orang pertama ('Aku') secara gramatikal dalam suatu teks naratif, maka pencerita tersebut termasuk dalam pencerita intern atau character-bound narator $(\mathrm{CN})$, sehingga narator dalam novel Telegram ini adalah narator internal. Biarpun berdasarkan hasil analisis data, tokoh Aku tidak menjadi satusatunya narator terbukti dengan menjadinya tokoh Rosa pada bab I sebagai narator serta tokoh teman Aku sebagai narator tingkat kedua pada bab III dan munculnya narator eksternal atau narator yang bukan tokoh pada bab III yang menarasikan cerita, tokoh Aku pada novel ini tetaplah menjadi narator utama karena biarpun ada narator lain pada bab-bab tertentu, tetap saja tokoh Aku menceritakan hampir semua kisah dalam novel ini. Berdasarkan analisis data yang telah dilakukan, maka dapat disimpulkan tipe narator yang terdapat dalam novel Telegram karya Putu Wijaya adalah narator internal $(\mathrm{CN})$ yaitu tokoh Aku dan Rosa, serta narator eksternal (EN) yaitu sesuatu yang tidak diketahui identitasnya. Penggunaan narator internal $(\mathrm{CN})$ bertujuan untuk memberi kesan bahwa yang diceritakan dalam suatu cerita adalah nyata. Adapun penggunaan narator eksternal (EN) bertujuan menyatakan kepada pembaca bahwa cerita yang terdapat dalam teks yang sedang dibacanya adalah suatu khayalan, imajinasi, atau cerita rekaan yang terdapat dalam kisah atau cerita yang sedang dibacanya. 
Pada dasarnya penggunaan pencerita internal $(\mathrm{CN})$ atau pencerita eksternal $(\mathrm{EN})$ yang digunakan oleh pengarang, membuat para pembaca mengambil suatu sikap baca tertentu. Pada novel Telegram, penggunaan narator internal $(\mathrm{CN})$ pada awal cerita bertujuan untuk menggiring pembaca agar langsung memasuki suatu peristiwa yang dialami tokoh utama. Selain itu dengan adanya perpindahan antara narator internal $(\mathrm{CN})$ dan narator eksternal (EN) dalam novel Telegram, menunjukkan bahwa pengarang ingin membuat bingung para pembaca dengan perpindahan bolak-balik antara $\mathrm{CN}$ dan EN. Perpindahan antara $\mathrm{CN}$ dan EN yang mengakibatkan cerita menjadi saling bertumpuk dalam novel juga menunjukkan bahwa pengarang memaksudkan genre cerita dalam novel Telegram adalah absurd.

Analisis narator berdasarkan teori naratologi sesungguhnya merupakan usaha untuk mengungkap struktur naratif sebuah cerita. Melalui dialog para tokoh cerita dapat terlihat gambaran atau peristiwa yang terjadi, sehingga dialog yang mengandung peristiwa dalam cerita, yang dituturkan para narator, menjadi dasar analisis struktur naratif cerita lebih lanjut.

\section{DAFTAR PUSTAKA}

Abidin, Aslan. 2011. Tubuh Terjajah dalam Novel Perburuan Karya Pramoedya Ananta Toer Sebuah Perspektif Pascakolonial (Tesis). Yogyakarta: Fakultas Ilmu Budaya UGM.

Bal, Mieke. 1985. Narratology: Introduction to The Theory of Narrative. London: University of Toronto Press.

Barthes, Roland. 2010. Imaji Musik Teks (cetakan pertama). Diterjemahkan oleh Agustinus Hartono. Yogyakarta: Jalasutra.
Endraswara, Suwardi. 2011. Metodologi Penelitian Sastra (Cetakan Pertama). Yogyakarta: CAPS.

Faruk. 2012. Metode Penelitian Sastra: Sebuah Penjelajahan Awal (cetakan pertama). Yogyakarta: Pustaka Pelajar.

Hudayat, Asep Yusup. 2007. Metode Penelitian Sastra (Modul). Bandung: Universitas Padjadjaran.

Moleong, Lexy J. 1990. Metodologi Penelitian Kualitatif (cetakan kedua). Bandung: PT Remaja Rosdakarya.

Pradopo, Rachmat Djoko. 2011. Beberapa Teori Sastra, Metode Kritik, dan Penerapannya. Yogyakarta: Pustaka Pelajar.

Qomariyah, U'um. 2007. Citra dan Pencitraan Anak dalam Novel Negeri Awan Merah Karya Fahri Asiza: Telaah Fokalisasi Mieke Bal (Tesis). Yogyakarta: Fakultas Ilmu Budaya UGM.

Rahmah, Yuliani. 2007. Dongeng Timun Emas (Indonesia) dan Dongeng Sanmai No Ofuda (Jepang), (Studi Komparatif Struktur Cerita dan Latar Budaya)(Tesis). Semarang: Universitas Diponegoro.

Ricoeur, Paul. 2012. Teori Interpretasi. Diterjemahkan oleh Masnur Hery. Yogjakarta: IRCiSoD

Teeuw. 2003. Sastera dan Ilmu Sastera (cetakan ketiga). Jakarta: PT. Dunia Pustaka Jaya.

Widdowson, H.G. 1997. Stilistika dan Pengajaran Sastra. Diterjemahkan oleh Dra. Sudijah, MA. Surabaya: Airlangga University Press.

Wijaya, Putu. 1977. Telegram (cetakan kedua). Jakarta: PT Dunia Pustaka Jaya. 